\title{
Information literacy - the missing link in education, with special reference to developing countries
}

\author{
James R. Isaac \\ NIIT Ltd. National Institute of Information Technology, \\ NIIT Ltd., 8 Balaji Estate \\ Kalkaji, New Delhi, 110 019, India \\ Tele + 91-11-6203210 (direct); 6203300; 6482054 \\ Fax+91-11-620333 or 6475892 \\ E-mail: isaac@internet.niit.co.in
}

\begin{abstract}
In their efforts to leapfrog into the Information Age, developing countries often attempt to catch up with the technologies and developments in the West. The only possibility of leapfrogging would be in the more effective exploitation of Information Technology towards human development. Such an exploitation can only be achieved through strategic initiatives concerning the very nature of information itself.

That exploitation is the information opportunity for developing countries. The paper identifies information understanding and information literacy as prime human resources if Information Technology is to be effectively exploited in developmental processes. For this opportunity to be seized, education and training, and not technologies, hold the key.
\end{abstract}

\section{Keywords}

Information handling, literacy, skills, industry training 
The Industrial Age was concerned with the production of material goods. Those goods were essentially concerned with the conversion of materials yielded by the earth and transformed into commodities for human use. Due to the very nature of materials, the production paradigm had to resort to the divide-and-rule policy in order to attain higher productivity and efficiency. Using the concept of the span-ofcontrol and the span-of-coordination the management (or social) pyramid structure can be derived and explained. The strategic, control and operational levels fall into perspective with the top management mainly handling external information implied uncertainties and complexities, heuristic - while the lower levels handle internal information - structured and organised, algorithmic. It is these aspects of information that are going to be fundamental to future educational concerns.

While the divide-and-rule policy certainly paid dividends in the Industrial Age, the paradigm was unfortunately carried over into other human activities. For example, offices adopted various forms of bureaucratic procedures and associated support staff structures resulting in various forms of gross mismatching, e.g., a lower division clerk is expected to be an expert typist and when s/he is promoted to the next hierarchical rung is too senior to just type so the upper division clerk turns into a decision maker. As a consequence, s/he does not type in the new job But perhaps the greatest harm of the divide-and-rule policy has been in education. This led to compartmentalisation and isolation as indicated in Figure 1.

\section{"DIVIDE \& RULE" POLICY INEDUCATION}

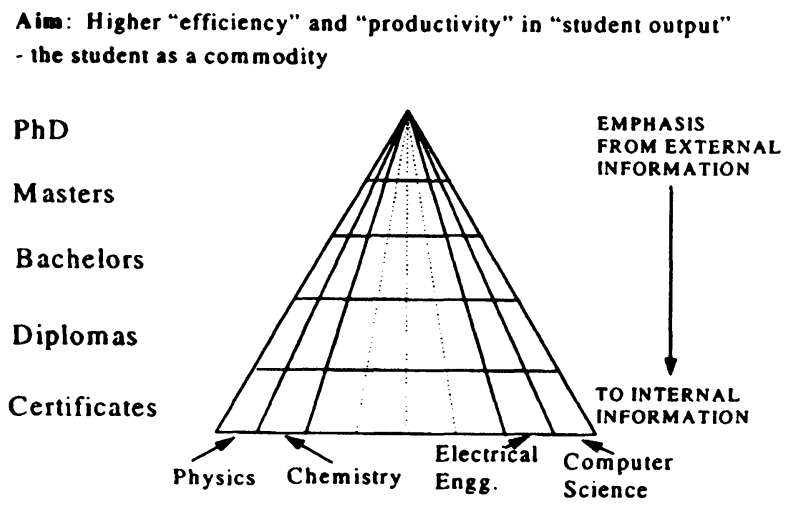

Figure 1 Divide and rule policy.

The figure indicates cells of specialised activities which are almost deliberately designed to work in isolation. It is this isolationist educational strategy that has led to unforeseen problems of pollution and environmental degradation and raised questions - not just the efficacy of education - but even of its very need in its present form. Ayn Rand (1971), for example, was caustic in her criticism of 
schooling, likening it to the process by which children were kidnapped, maimed, disfigured and trained to entertain European royalty. The modern tendency is to ignore the warnings of people such as Illich but it would be wise to recall the notion of his 'Learning Webs' which forecast Internet opportunities long before Internet was even conceived. However, even modern studies do conclude that education, as it is, should be reconceptualised, restructured and revitalised.

\section{Understanding the problems of the Information Age and its} technologies - especially in the context of developmental issues The Information Age quite obviously evolves around the notion of information (Machlup and Mansfield, 1983; Wright, 1988). However, this is unfortunately not the case - and the central theme of this paper is that information understanding and information literacy offer an immense opportunity to developing countries that should not be ignored. The usual thrust in most developing countries has been to attempt to leapfrog only in a technological sense. The aim has been to attempt to absorb technologies, especially the latest and the best. However this can be an exercise in futility. For example the educational systems' response towards technological needs has been to proliferate computer science courses at a time when even in the most advanced countries, the role of computer science is under question.

This should be more so in the case of developing countries which are resource restricted. Computer science as such aims at creating inputs for advanced developments in hardware and software, and needs high capital intensive research environments for actually delivering results. Such environments are not available in developing countries. No wonder then that computer science students from these regions seek greener pastures, causing an enormous burden on the countries' already restricted resources. The main issue is whether developing countries should plan for technology innovation or whether they should work towards technology absorption.

Table 1 Technology innovation and creativity versus technology absorption

PARAMETER

Base education and training

Focus of education and training
TECHNOLOGY INNOVATION

Computer science \& computer technology

Computer theory, extensive knowledge of hardware/software; computer applications not taken seriously.
TECHNOLOGY ABSORPTION
General education, information literacy and skills plus computer skills

Basic education on potential application areas not computers; computer and 
Tools almost completey ignored.

Student attitudes

Leads to

Significance

Prefers computer R\&D

environment, shuns

computer applications.

Innovation and creativity in capital intensive $R \& D$ environment

Low, even could be very low productivity (in general)

Innovation in a technological environment information skills acquired through training in problem solving and tools

Amenable to applicationoriented training; prepared for a wide range of applications.

Wide range of computer applications

High, cost effective and in wide spectrum

Technology absorption into society in any environment

Table 1 clearly indicates that the strategy for rapid development, particularly of society, must obviously aim at technology absorption.

\section{Problems of the Information Age}

While there is much said about the opportunities of the Information Age little is done to even understand the Information Age (Machlup and Mansfield, 1983). Why is this? Basically, the problem lies in understanding fundamental economic principles. In place of material goods and commodities we now have to contend with information goods and commodities. The fundamental acceptance of the barter principle is challenged. When a material good was sold, it exchanged hands for money paid and all was well. But an information commodity, when it is sold, still remains with the user, thus upsetting all previous notions of value. Consider Table 2 shown below. 
Table 2 Material commodities versus information commodities

\begin{tabular}{|c|c|c|}
\hline Parameter & Material Goods & Information Goods \\
\hline Type & Tangible & Intangible \\
\hline $\begin{array}{l}\text { Natural resource } \\
\text { required in production? }\end{array}$ & Yes & No \\
\hline Replicability & Difficult, costly & Easy, very low cost \\
\hline Durability & Low & High \\
\hline Transportability & Difficult, expensive & $\begin{array}{l}\text { Very easy, very low } \\
\text { cost }\end{array}$ \\
\hline On usage. . . & Gets depleted & Does not deplete \\
\hline Number of consumers & Restricted & $\begin{array}{l}\text { Infinite number } \\
\text { (theory!) }\end{array}$ \\
\hline Life cycle & Single & Single or multiple \\
\hline Appropriability & $\begin{array}{l}\text { More-for-me, means less } \\
\text { for you, exchangeable }\end{array}$ & $\begin{array}{l}\text { Usually public } \\
\text { good, } \\
\text { shareable but not } \\
\text { exchangeable }\end{array}$ \\
\hline Special features & Nothing specific & $\begin{array}{l}\text { Expandable, } \\
\text { increases with } \\
\text { use, compressible, } \\
\text { summarisable, } \\
\text { integratable, } \\
\text { value over time - } \\
\text { unpredictable }\end{array}$ \\
\hline Utility & As originally intended, or as-is & $\begin{array}{l}\text { Value add to all } \\
\text { phases of } \\
\text { human } \\
\text { activity }\end{array}$ \\
\hline
\end{tabular}

This study clearly indicates the dilemma of understanding information economics and is the start of acquiring information literacy. This is the fundamental reason why studies on information and its use become fundamental to the problems of the Information Age. Despite the formidable view presented of information value being 
very difficult to pinpoint there are studies that show that effective information usage does convert to money and productivity. In fact, with the concept of globalisation hovering over even developing nations the need to be competitive in production can become crucial. Hence they must use the earliest opportunity to become information sensitive.

\section{THE EDUCATIONAL SHIFT FROM THE INDUSTRIAL AGE TO THE INFORMATION AGE PARADIGM}

The problem is exacerbated when we consider fundamental educational paradigm shifts that take place when we move into the Information Age. So it would be worthwhile to make in-depth studies on the implications of the shifts. Let us first take an in-depth look at the changing educational drives that result.

The table clearly indicates the radical changes that have to be made in educational planning for the future and here lies the real opportunity for developing nations. The educational systems of some developing nations are still in a transitional stage, and, unlike technological leapfrogging, educational leapfrogging can become a reality with proper planning.

Table 3 Educational drives and paradigm shifts

\begin{tabular}{|c|c|c|}
\hline Item/characteristic & Industrial age & $\begin{array}{l}\text { Information } \\
\text { age }\end{array}$ \\
\hline Duration, time spent, & $\begin{array}{l}\text { Preparatory for life, } \\
\text { early in life, one } \\
\text { time }\end{array}$ & $\begin{array}{l}\text { Lifelong, goal } \\
\text { continuous }\end{array}$ \\
\hline Stress, focus & $\begin{array}{l}\text { Science/Technology } \\
\text { orientation }\end{array}$ & $\begin{array}{l}\text { People, } \\
\text { management, } \\
\text { organisation } \\
\text { oriented }\end{array}$ \\
\hline Brain Focus & Left hemisphere & Right hemisphere \\
\hline Societal Models & $\begin{array}{l}\text { Factory model, } \\
\text { centralising }\end{array}$ & $\begin{array}{l}\text { Information model, } \\
\text { distributive, } \\
\text { dispersive, }\end{array}$ \\
\hline Driving Strategy & $\begin{array}{l}\text { Atomization } \\
\text { Divide and rule }\end{array}$ & $\begin{array}{l}\text { Aggregation } \\
\text { Integrate, collaborate }\end{array}$ \\
\hline Goal of Education & Degrees, diplomas & $\begin{array}{l}\text { Knowledge, } \\
\text { experience } \\
\text { capability }\end{array}$ \\
\hline
\end{tabular}


Knowing/doing relationship

Scope/Effectiveness of skills

Use of Information tools

Data collection, storage processing

Restricted to physical activities, task specific skill saturates, low returns isolated from doing (practice); knowledge for its own sake.

Knowing and doing integrated; knowledge redefined as knowledge + practice

Information skills at all levels of management, wide range, very high returns

Conversion of data to

information to knowledge

Nature of computing Task oriented

From corporate hierarchies
Organisational computing, synergistic

To corporate networks

\section{What are the resources for such an educational shift?}

Due to the perpetual resource crunch in developing nations whenever any change for the better is mentioned resources come to the forefront. However, when we wish to leapfrog into the Information Age through education there is no need for extensive technological expenditures. What is required is a deep study of how education can sensitise entire populations into understanding the use of information as an economic tool. This can be done only through understanding the role of information sensitivity in the educational process and this calls for an understanding of information skills and information literacy.

\section{Identifying core information skills}

Fortunately much work has been done on understanding information skills but educational systems prefer to ignore these studies. Core information skills have been identified by Vockell and van Deusen (1989):

- Focusing skills: Defining problems, setting goals;

- Information gathering skills: Observing, formulating questions;

- Remembering skills: Encoding, recalling;

- Organising skills: Comparing, classifying, ordering, representing;

- Analysing skills: Identifying attributes, components, relationships and patterns, main ideas, errors; 
- Generating skills: Inferring, predicting, elaborating;

- Integrating skills: Summarising, restructuring;

- Evaluating skills: Establishing criteria, verifying.

It is an interesting exercise to compare these with the Taxonomy of Educational Objectives (Bloom, et. al., 1956) - knowledge, comprehension, application, analysis, synthesis and evaluation - and then attempt to order them into the Bloom pattern.

\section{A practical example of teaching and applying information skills}

The company I belong to is among the world's largest computer training endeavours. Annually they train over 150000 students on computer skills. Formal education basically undertakes to teach 'only-what-it-knows'. This may seem rather obvious but 'What is it that the student has to learn?' is a far more serious question. Yet it usually remains unanswered.

If students are to become computer professionals how can they be helped during their studies? Computer professionals, or for that matter any other professionals, are not filled with only technical knowledge. They must acquire world knowledge. Usually when a student moves into the world of the professional, s/he feels like a fish out of water - there seems to be so much that $s /$ he doesn't know. The reason is that formal studies stick to logical, science-based approaches while real life does not.

To remedy this we brought out an innovative integrated monthly magazine $I T$ Digest, an abstracting and classifying service. However, we added a novel element. Usually abstracting services are confined to well-defined boundaries of what they cover and they restrict themselves to one field and level of source documents. ITDigest violates this principle by abstracting and classifying from three levels of sources: daily newspapers (general and financial), magazines and journals (Indian and international). The sources vary from informal to the formal and yet they are classified in the same way. This is where the integration of information takes place. For the students' world view it is not sufficient for them to stick to just technical topics. They must understand, especially in developing countries, how the policy of the government is reflected in the process of technology absorption and this is better understood through newspaper articles than through journals. The processes enables one to put oneself into a total information environment in the business of information technology.

The next step was to identify how the various information skills could be woven into a learning structure. This opportunity was offered to the student through a course titled Information Search and Analysis Skills (ISAS). The student was exercised through the process of using IT-Digest as an information laboratory in which to find solutions to fairly open-ended professional questions that would never find a place in formal education. The course clearly proves the power of such a methodology in getting students to be information sensitive and to acquire information skills. This experience gives us the feeling that this methodology can be extended into other fields of educational activity though information technology serves as an ideal base. 


\section{LEAPFROGGING THROUGH THE ACQUISITION OF INFORMATION SKILLS}

The absorption of IT into the developmental processes though extremely promising has its pitfalls. The tendency is to do it through the acquisition of technology into a population that is information insensitive. Developing countries would open up new opportunities for themselves if they stop putting the cart before the horse and turn their educational systems into a conscious acquisition of information skills. The ISAS methodology could be initiated at a much lower level of education. Information skills also can be honed through a conscious training of students to make use of libraries in an effective manner. In fact, the library can take the place of the IT-Digest as an information skill learning environment.

If students are trained in information skills on a large scale then the absorption of IT into the developmental processes takes on an entirely new shade of meaning. It is only then that the true power of IT can be released into effective developmental strategies.

\section{4}

\section{REFERENCES}

Bloom, B.S., Engelhart, M.D., Furst, E.J., Hill, W.H. and Krathwohl, D.R. (1956) Taxonomy of Educational Objectives, Handbook I: Cognitive Domain. David McKay Co., New York.

Hills, A. (1991) Teaching information networking. IEEE Spectrum, October, 1991.

Isaac, J.R. (1997) Information Systems: Changing Paradigms in Society, Management, Education andTraining. Proceedings of SCI/ISAS Conference, Caracas, Venezuela, July 7-11, 1997.

Jonscher, C. Information resources and economic productivity. Information, Economics and Policy, 1(1), 1983.

Machlup, F. and Mansfield, U. (1983)The Study of Information: Interdisciplinary Messages. John Wiley, New York.

Rand, Ayn. (1971) The New Left: The Anti-Industrial Revolution. Signet, New York.

Vockel, E. and van Deusen, R.M. The Computer and Higher Order Thinking. Mitchell Publishing Co., Watsonville, CA.

Wright, R. (1988) Three Scientists and Their Gods: Looking for Meaning in an Age of Information. Times Books, New York.

5

\section{BIOGRAPHY}

Prof. J.R.Isaac completed his engineering studies in Bangalore, India and at the Carnegie Institute of Technology (now Carnegie Mellon University) in Pittsburgh, PA, USA. He worked for two years at the IBM Research and Product Development Labs in Poughkeepsie, N.Y. From 1958 until 1990, he taught electronics and computer science courses - the last 29 years at the Indian Institute of Technology (IIT) at Bombay, India. On retirement from IIT-B in 1990, he joined 
NIIT (National Institute of Information Technology) Ltd., New Delhi as an advisor and he is also Director of the Institute for Research in Information Sciences (IRIS), a division of NIIT. He is the editor of a monthly abstracting and indexing service, IT-Digest. He also heads a project to create an 'Interactive Learning Environment' for disabled persons who cannot use a QWERT keyboard. His current research interest lies in studying information age impacts and paradigms. 